\title{
OUTLINES OF THE SIBERIAN PLATFORM SEQUENCE STRATIGRAPHY IN THE LOWER AND LOWER MIDDLE CAMBRIAN (LENA-ALDAN AREA)
}

\author{
Andrey Yu. ZHURAVLEV \\ Palaeontological Institute, Russian Academy of Sciences. Profsoyuznaya ul. \\ 123. Moscow 117647. Russia. E-mail: azhur@paleo.ru
}

\begin{abstract}
Zhuralev, A.Y. 1998. Outlines of the Siberian Platform sequence stratigraphy in the Lower and lower Middle Cambrian (Lena-Aldan area). [Rasgos generales de la estratigrafía secuencial de la Plataforma Siberiana en el Cámbrico Inferior y Cámbrico Medio bajo (área Lena-Aldan)]. Revista Española de Paleontología, nºxtr. Homenaje al Prof. Gonzalo Vidal, 105-114. ISSN 0213-6937.
\end{abstract}

\begin{abstract}
The development of Cambrian reefal complexes on the inherited pre-Cambrian uplifts determined a subdivision of the Siberian Platform basin into three facies belts: western saliferous basin, eastern open shelf, and transitional reefal belt. Facies shifts which affected all belts emphasised the sequence and parasequence boundaries. The study of the stratotype area of the Russian Lower Cambrian stages (middle courses of the Aldan and Lena rivers) allowed us to distinguish four (third-order?) sequences spanning the Tommotian-lower Mayan interval. The sequence boundaries, except for the base of the Nemakit-Daldynian Stage, are restricted to intrazonal levels rather than to the boundaries between stages and even between zones. Such a relationship between biostratigraphic and sequential boundaries excludes significant chronostratigraphic hiatuses in the Siberian Early Cambrian time scale. This fact together with high fossil content, and good magnetostratigraphic, chemostratigraphic ( $\mathrm{C}$ and $\mathrm{Sr}$ isotopes), and radiometric data show that stable cratons located at low latitudes keep a better record of events serving the chronostratigraphic basis. A special attention should be paid to the fact of the absence of a pronounced correlation between biostratigraphic and sequential events.
\end{abstract}

Key words: Lower Cambrian, sequence stratigraphy, Siberian Platform.

\begin{abstract}
RESUMEN
El desarrollo de complejos arrecifales cámbricos sobre las elevaciones heredadas de tiempos precámbricos determinó la subdivisión de la cuenca de la Plataforma Siberiana en tres cinturones de facies: cuenca salina occidental, plataforma abierta oriental y cinturón arrecifal transicional. Los desplazamientos de las facies, que afectaron a los tres cinturones, enfatizaron los límites entre secuencias y parasecuencias. El estudio del área tipo de los pisos rusos para el Cámbrico Inferior (cursos medios de los ríos Aldan y Lena) nos ha permitido distinguir cuatro secuencias (probablemente de tercer orden) que abarcan el intervalo Tommotiense-Mayiense inferior. Excepto para la base del Piso Nemakit-Daldyniense, los límites de secuencia están restringidos a intervalos intrazonales más que a límites entre pisos o zonas. Este tipo de relaciones entre los límites bioestratigráficos y los secuenciales excluye la posibilidad de hiatos cronoestratigráficos significativos en la escala temporal para el Cámbrico Temprano de Siberia. Este hecho, junto con el rico contenido fósil y la abundancia de datos magneto y quimioestratigráficos (de isótopos de $\mathrm{C}$ y Sr) así como radiométricos, muestra que cratones estables situados a bajas latitudes guardan un mejor registro de eventos útiles para construir una escala cronoestratigráfica. En este sentido, hay que prestar especial atención a la ausencia de una correlación marcada entre eventos bioestratigráficos y secuenciales.
\end{abstract}

Palabras clave: Cámbrico Inferior, estratigrafía secuencial, Plataforma Siberiana.

\section{INTRODUCTION}

The Siberian Platform is one of the key regions for the study of the Cambrian. Fossiliferous, flat-lying platformal deposits cut out by multiple rivers and penetrated by boreholes are outlined in numerous publications which brought out an elaborated picture of Cambrian bio-, magneto- and chemical stratigraphy as well as facies analysis and ecological features of Cambrian organisms and communities. The Cambrian sections of the Siberian 


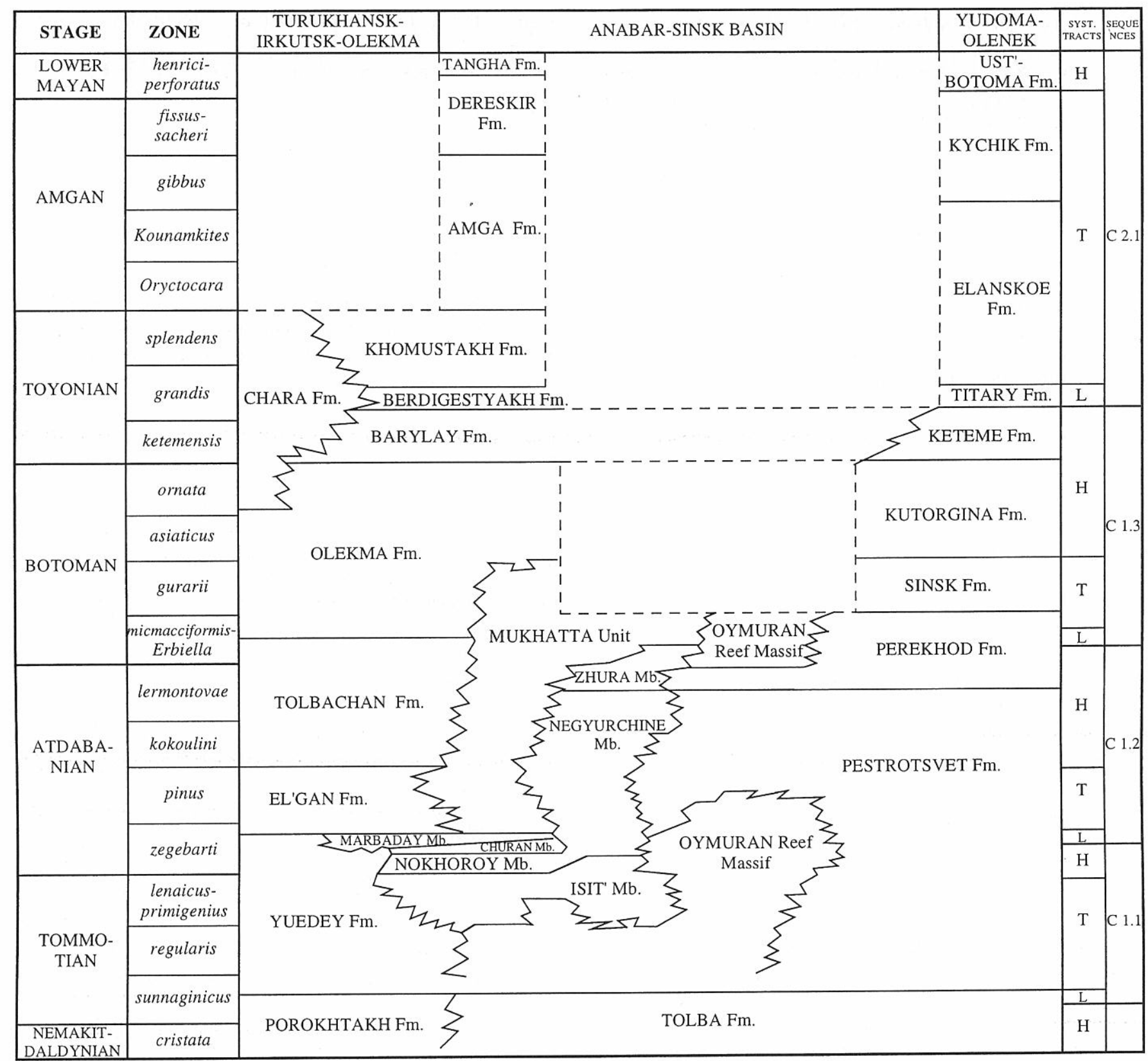

Figure 1. Lower and lower Middle Cambrian stratigraphic units, sequence stratigraphic and biostratigraphic frameworks of the southern Siberian Platform (Lena River middle courses basin). Time lines are horizontal but figure is not to scale. Keys for systems tracts: $\mathrm{H}=$ highstand; $\mathrm{L}=$ lowstand; $\mathrm{T}=$ transgressive.

Platform served as the basis for the Lower and Middle Cambrian stage and zonal time scale accepted in the former Soviet Union and now in Russia.

\section{Palaeogeographic subdivision}

The Lower and lower Middle Cambrian of the Siberian Platform has three major facies basins (Arkhangel'skaya et al., 1960; Khomentovsky and Repina, 1965; Bobrov et al., 1968; Savitsky et al., 1972; Pisarchik et al., 1975; Zhuravleva, 1979; Astashkin et al., 1991).

The south-western Turukhansk-Irkutsk-Olekma Facies Basin was a region of dolostone, sulphate and common salt deposition. Limestones are scarce, consisting mainly of Tommotian and Atdabanian calcimicrobial reefs and trilobite-containing limestones deposited during transgression maxima. Evaporites progressively diminished eastward. Along the Lena River middle courses, these basin is spread out upstream Malykan village (Fig. 1).

The transitional Anabar-Sinsk Facies Basin is a relatively narrow tract of calcimicrobial-archaeocyathan reefs and skeletal or ooid calcarenites. It is about $200 \mathrm{~km}$ wide along the Lena River middle courses and narrows to the north-west, where it lies mostly in the subsurface (Shabanov et al., 1987). This basin is subdivided into back reef shoal, reef barrier (core reef) and fore reef slope facies (Savitsky et al., 1980; Varlamov and Sundukov, 
1979). Along the Lena River middle courses, these facies occupy areas from Malykan village to the Mukhatta River mouth, from the Mukhatta River mouth to the UlakhanTaryng River mouth (Oymuran Reef Massif) and from the Ulakhan-Taryng River mouth to the Ulakhan-KyyryTaas River mouth, respectively (Fig. 1).

The Yudoma-Olenek Facies Basin occupies the eastern and north-western parts of the Siberian Platform and contains open marine carbonates. These facies are represented by Tommotian-Atdabanian red argillaceous limestone and mudstone, and Botoman-Amgan dark, bituminous limestone and chert with features of slope deposition (Gurari, 1945; Sukhov and Pereladov, 1979). However, Rozanov and Zavarzin (1997: fig. 2) do not exclude that this basin was a shallow dysaerobic semiclosed estuary during the middle Early-early Middle Cambrian time. Along the Lena River middle courses, this basin is spread out downstream the Ulakhan-KyyryTaas River mouth (Fig. 1).

Palaeogeographic facies distribution patterns suggest that the Anabar-Sinsk facies represented some sort of barrier complex separating the largely evaporitic facies in the west from deeper water, deep ramp and slope facies in the east (Astashkin et al., 1984; Budnikov et al., 1995).

\section{Time scale}

Despite facies contrasts, abundant and diverse fossils (over 1,200 species of about 500 genera) provided a firm basis for correlation between these belts at a zonal level. In addition, the Anabar-Sinsk and Yudoma-Olenek basins were peculiar by their diverse cosmopolitan elements.

The following formal stages are established on the Siberian Platform in ascending order: Tommotian, Atdabanian, Botoman, Toyonian (Lower Cambrian), Amgan and Mayan (Middle Cambrian). Recently, the informal Nemakit-Daldynian Stage (or its synonym Manykayan Stage) is commonly used as the lowermost Cambrian pre-Tommotian division. However, in Russia it is a correlative equivalent of the Rovno Horizon crowning the Vendian System. The Nemakit-Daldynian Stage may be correlated, at least in its upper part, with the basal Cambrian of Newfoundland where the Precambrian/ Cambrian boundary stratotype occurs (Zhuravlev, 1995; see also Rozanov et al., 1997). It should be emphasised that the lowermost Tommotian (Nochoroicyathus sunnaginicus) zone by its original as well as official definitions, that means including the uppermost metres of the Ust'yudoma Formation, Yudoma Group (Rozanov et al., 1969; Spizharski, Ergaliev et al., 1983; Spizharski, Zhuravleva et al., 1986), is a partial equivalent of the uppermost Nemakit-Daldynian (Purella cristata) zone sensu Khomentovsky and Karlova (1993).

Except for the stratotype of the Nemakit-Daldynian Stage, all Lower and Middle Cambrian stage stratotypes mentioned above are established in the south-western Siberian Platform, in the Aldan Anteclise, along the Aldan (Tommotian Stage), Lena (Atdabanian and Toyonian stages), Botoma (Botoman Stage), Amga (Amgan Stage), and Yudoma and Maya (Mayan Stage) rivers. Thus, the stratotypes embrace the south-eastern Anabar-Sinsk Basin (Tommotian, Atdabanian, Botoman in part, Toyonian, and Amgan stages) and south-western Yudoma-Olenek Basin (Botoman in part and Mayan stages) (Savitsky et al., 1980).

\section{SEQUENCE RECONSTRUCTION}

\section{Pre-Tommotian hiatus}

Within the stratotype area of the Tommotian Stage (Aldan River middle courses), the basal layers of the lowermost Tommotian (sunnaginicus) zone are restricted to the uppermost $1.5-2.0 \mathrm{~m}$ of the Ust'yudoma Formation where the first diagnostic Tommotian fossil assemblage occurs in glauconitic shelly grainstone known as Bed 8 (Rozanov et al., 1969: 27). Commonly the origin of this layer is explained by the subsequent impregnation of the grainy material from the overlying Pestrotsvet Formation along karstic fissures developed on the Ust'yudoma surface during the pre-Pestrotsvet time (e.g., Khomentovsky and Karlova, 1993). In turn, this suggestion brought about a developed hypothesis on a sizeable sub-Tommotian hiatus in south-western Siberia (Knoll, Grotzinger et al., 1995; Knoll, Kaufman et al., 1995; Brasier et al., 1996; Kaufman et al., 1996).

First of all, Bed 8 is a layer continuous over two hundred metres (and not "for a few metres along strike", cf. Khomentovsky and Karlova, 1993: 42) without any features of karstic sinks and fissures connecting it with the Pestrotsvet Formation but with distinct crosslamination (Fig. 2). Similar microfacies are common in the upper Ust'yudoma Formation within entire southern Anabar-Sinsk and south-eastern Yudoma-Olenek basins (Fedorov, 1982; Khomentovsky et al., 1990) which is accumulated during a highstand tract. Small shelly fossils are not restricted to the glauconitic grainstone but are present in overlying and underlying mudstones (Fedorov et al., 1992: 16). In addition, the observed faunal, microfacies, geochemical, mineralogical, and isotopic differences between Bed 8 and basal Pestrotsvet Bed 12 (Ivanovskaya, 1980; Ivanovskaya and Tsipursky, 1982; Nazarov et al., 1983; Magaritz et al., 1986; Fedorov et al., 1992) do not allow us to explain the origin of Bed 8 by karstic processes.

The suggestions about a sizeable pre-Tommotian hiatus are based on carbon isotopic correlation of northern Siberian sections with southern Siberian ones and some theoretical suggestions concerning rates of speciation (Knoll, Grotzinger et al., 1995; Kaufman et al., 1996). Pure isotopic correlation can not be accepted as reasonable one because even adjacent sections of the same basin are characterised by a difference in the magnitude and number of isotope excursions comparable with that in remote parts of the region (e.g., cf. plots on Kirschvink et al., 1991: fig. 2; or on Brasier et al., 1994: figs. 6, 7 and 8; and on Kaufman et al., 1996: fig. 9). Neither the claim on the simultaneous appearance of "more than 100 species" in basal Tommotian rocks of south-eastern Siberia (Kaufman et al., 1996: 517) can be 


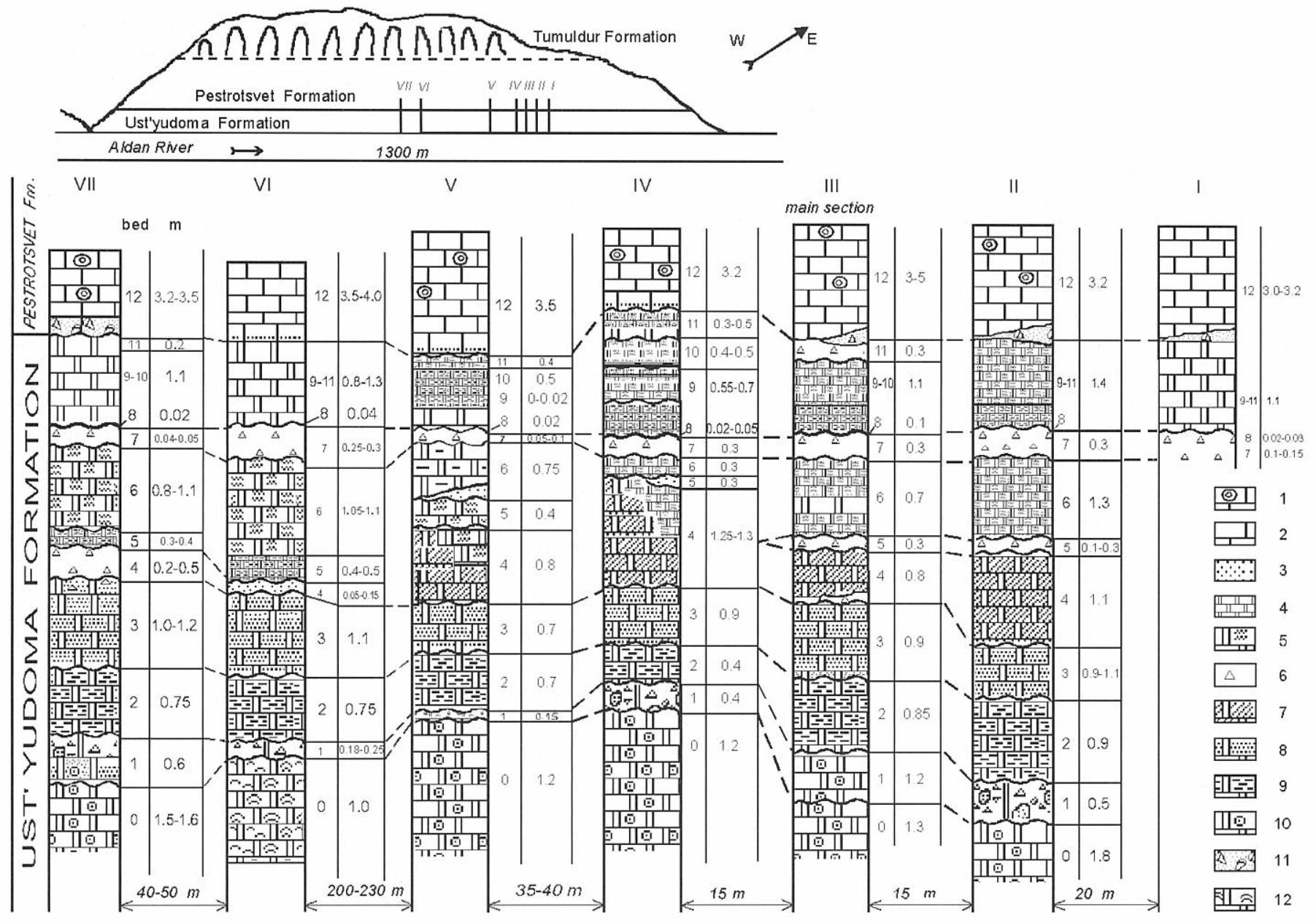

Figure 2. Lithology of the boundary strata of the Ust'yudoma and Pestrotsvet formations in the Ulakhan-Sulugur section, Aldan River middle courses, southern Siberian Platform. Bed 8 of section IV is the stratotype of the Tommotian Stage lower boundary; Bed 12 corresponds to the Sunnagin Member of the Pestrotsvet Formation; beds 8-12 correspond to the Nochoroicyathus sunnaginicus Zone of the Tommotian Stage. 1=Archaeocyathan reefal limestone. $2=$ Greenish mudstone-wackestone. 3=Glauconitic packstone. 4=Parallel-laminated dolomitic mudstone. $5=$ Cryptomicrobial laminated dolostone. $6=$ Dolomitic flat-pebble intraclast. $7=$ Cross-laminated dolomitic grainstone. $8=$ Dolomitic grainstone. 9=Argillaceous dolomitic mudstone. $10=$ Cross-laminated oolitic grainstone $11=$ Shelly floatstone. $12=$ Stromatolitic dolostone.

accepted. The list of species compiled by Khomentovsky and Karlova (1993) contains indeed 113 species but in the entire southern Siberia (several thousand square $\mathrm{km}$ ) and not in a single section. A number of them are synonyms (e.g., Coleolella billingsi and Spinulitheca billingsi, Archaeospira regularis and Yangtzespira regularis, and Mellopegma indecora and Anabarella indecora, respectively, are objective synonyms; and Egdetheca aldanica is a junior synonym of Exilitheca multa even according to the authors of these taxa, Val'kov et al., 1983: 69). On the second hand, these species do not appear simultaneously and some authors recommend to subdivide the sunnaginicus Zone into 2-3 separate zones distinct by their fossil assemblages (Pel'man et al., 1990). Thirdly, rates of speciation have to be counted for the entire Tommotian interval to see their distinctness or indistinctness from the NemakitDaldynian/Tommotian boundary interval. For instance, the speciation rates of archaeocyaths are higher at the sunnaginicus/regularis Zone boundary rather than at the Nemakit-Daldynian/Tommotian boundary (Zhuravlev and Wood, 1996: fig. 2A). Finally, if pre-Tommotian hiatus could be indeed observed on the Olenek Uplift and western Anabar Area (Knoll, Grotzinger et al., 1995; Knoll, Kaufman et al., 1995; Kaufman et al., 1996), this would not be the case for the Aldan Anteclise and northwestern Siberian Platform (Igarka Area). In the later area, along the Sukharikha River, a sequence, which is very similar to the Aldanian one, is observed. Here highstand tract deposits of the uppermost Sukharikha Formation contain a typical sunnaginicus assemblage of archaeocyaths and small shelly fossils which continues to occur in the overlying transgressive deposits of the reddish Krasny Porog Formation (Rozanov et al., 1969: 48). The same is probably true for the Yudoma-Maya Area of the Yudoma-Olenek Basin where the Pestrotsvet Formation conformably lies on the Ust'yudoma Formation (Khomentovsky et al., 1990). 


\section{Sequence C1.1}

Thus, the claimed pre-Tommotian hiatus is actually within the sunnaginicus Zone and is related to the Ust'yudoma/Pestrotsvet Formation boundary which shows features of unconformity including karst-related dissolution features (Khomentovsky and Karlova, 1993). On the Lena River (Isit' section), the uppermost Tolba Formation, which is a correlative equivalent of the Ust'yudoma Formation, bears desiccation-cracked polygons at the bedding plane in microbially laminated dolostone. The biostratigraphic correlation of this hiatus with a similar one over the Anabar Area (Manykay/ Medvezh'ya contact) and Igarka Area (Sukharikha/ Krasny Porog contact) implies a type I unconformity for the base of sequence C1.1.

The sequence $\mathrm{C} 1.1$ begins in the Aldan River from the transgressive open-marine limestones of the Pestrotsvet Formation represented by the basal unit (Sunnagin Member) of dolomitic ooid grainstone and shelly grainstone, packstone and wackestone incorporating small rare archaeocyathan-calcimicrobial framework reefs (Riding and Zhuravlev, 1995) and reddish argillaceous mudstone and wackestone with larger calcimicrobial-archaeocyathan and archaeocyathancalcimicrobial reefs representing a subtidal, low energy, open-shelf environment.

In the Lena River, similar reddish reef-bearing deposits (Oymuran Reef Massif) transgressively overlie Nemakit-Daldynian to lowermost Tommotian Tolba Formation dolostone. Typical sediments are centimetrescale interbedded, slightly dolomitic, argillaceous mudstone to calcareous siltstone. Red argillaceous sediments contain numerous trace fossils including Rhizocorallium, Chondrites (which are indicative of subtidal Cruziana ichnofacies) and, in the Atdabanian part, Plagiogmus (Rozanov and Sokolov, 1984). Grey, yellowish or reddish calcareous beds are richer in bioclasts (wackestone to floatstone) including large archaeocyath cups and plates, hyoliths, chancelloriid sclerites, brachiopods, hexactinellid spicules, other small shelly fossils, mesoclots as well as occasional burrows. Rounded flat-pebbled intraclasts up to $1-2 \mathrm{~cm}$ in diameter and composed of burrowed hyolith mudstone or micrite are common. Large hyoliths form packstone lags in which they are typically current aligned. All bioclasts except archaeocyaths and mesoclots are generally neomorphosed to microspar and fine pseudospar. Glauconite is minor. Some thin $(1 \mathrm{~cm})$ beds are crosslaminated. These burrowed, rippled and cross-laminated sediments were collectively deposited in wholly shallow shelf, subtidal environments that were episodically affected by storm reworking producing hummocky crossstratification and alternating laminated-burrowed units. Such sediments are interpreted as the transgressive systems tract of the overall Pestrotsvet Formation (Tommotian-lowermost Atdabanian) sequence (Kruse et al., 1995). In the core reef facies, the transgressive tract is expressed in the retrograding of reddish argillaceous mudstone of the Yudoma-Olenek Basin and in the weakening of the reef-building. In the Turukhansk-
Irkutsk-Olekma Basin, Yuedey Formation was accumulated which was lithologically very similar to the Pestrotsvet Formation but more dolomitic.

In the back-reef facies, an Atdabanian Nokhoroy Member of grainstones and wackestones, intensively burrowed and less argillaceous than underlying sediments, begins the highstand tract. The most typical of this member are Aulophycus facies. The geopetal structures with blocky calcite cement and distinct dolomitized wall lining prove that these were open burrow systems. These Ophiomorpha-like trace producers (Aulophycus) occupied shifting lime muds in shoal agitated lagoonal conditions (Morrow, 1978; Zhuravlev, 1996). In addition, the Nokhoroy Member bears burrowed wackestone containing meshes of Girvanella filaments intercalating within burrowed and microbially laminated lime mudstone and tidal-bedded dolostone (Debrenne and Zhuravlev, 1996), which reveal schizohaline pond deposits of intertidal flats (Pratt et al., 1992). Succeeding Churan Member through crossbedded oolite with local tepees is thought to represent ooid-shoal highstand system tract deposition (Kruse et al., 1995). On the Aldan River, the highstand tract is represented by argillaceous wavy laminated and blocky dolostone of the lagoonal (?) Tumuldur Formation. Corereef are expressed by a new progradation of the Oymuran Reef.

\section{Sequence C1.2}

The lower Atdabanian Marbaday Member consists of Girvanella boundstone, grainstone and finely crystalline peritidal dolostone with desiccation cracks and fenestrae. It shows some features of karst (Varlamov and Sundukov, 1979; Khomentovsky and Gibsher, 1983) and represents the lowstand tract deposits of the sequence C1.2. The Overlying El'gyan Formation includes weakly bituminous dolostone (Varlamov and Sundukov, 1979) and corresponds to the transgressive tract deposits in the Turukhansk-Irkutsk-Olekma Basin. In its innermost area, saliferous deposits gave place to calcimicrobial reefs of the Osa Horizon (Mel'nikov et al., 1989).

In the back-reef facies, middle-upper Atdabanian Negyurchine and Zhura members are highstand tract lithological equivalents of the Nokhoroy and Churan members, respectively. However, there are numerous layers rich in Epiphyton and Renalcis, and several levels of prolate bioherms in the Negyurchine Member.

Core-reef and fore-reef facies are represented during the highstand tract by the Perekhod Formation members I to III. These members are built of multiple shelf shoaling up cycles of thin bedded grey argillaceous mudstone at the bottom and of Epiphyton-type (mostly Gordonophyton and Tubomorphophyton) prolate biostromes consisting of numerous distinct kaliptrae (0.2-1.0 $\mathrm{m}$ in diameter) at the top. Towards the YudomaOlenek Basin biostromes pinchout. In the TurukhanskIrkutsk-Olekma Basin, the Tolbachan Formation comprises the highstand tract. It consists of dolomitic stromatolites with subordinated flat-pebble conglomerate, grainstone and ooid shoals (Varlamov and 
Sundukov, 1979). In the innermost part of the basin, common salts of the Bel'sk Formation were accumulated (Astashkin et al., 1993).

\section{Sequence C1.3}

To the west of the Oymuran Reef Massif, the Mukhatta Unit (lower Botoman) represents subtidal deposits of the next sequence in the back-reef facies (Varlamov and Sundukov, 1979). The lowstand tract deposits within the Oymuran Reef Massif are characterised by conglomerate and grainstone formed during the reef reworking. In the Turukhansk-IrkutskOlekma Basin, the lowstand tract is represented by the uppermost Tolbachan Formation. In the Yudoma-Olenek Basin, the lowstand tract deposits are represented by yellow peritidal dolostone with fenestrae in the lower part of Member IV (lower Botoman) of the Perekhod Formation (Marker Bed "v"-"g" of Khomentovsky and Repina, 1965).

The uppermost Perekhod Formation and overlying Sinsk Formation compose the transgressive tract with the maximum flooding surface (parasequence boundary) at the base of the Sinsk Formation. Some beds of the uppermost Perekhod Formation and the entire Sinsk Formation microfacies include bituminous limestone, chert, and argillaceous, siliceous, or calcareous, sapropelic black shales. All lithologies contain abundant syngenetic framboidal pyrite and $\mathrm{C}_{\text {org }}$ (up to $17.2 \%$ in shales; Zelenov, 1955). The shales commonly show no bioturbation and well-expressed even, submillimetric lamination consisting of an alternation of light calcite and brown clay-rich laminae. The calcitic laminae contain pellets, intraclasts and abundant monospecific acritarchs of Micrhystridium group. The clay-rich layers contain finely disseminated organic matter. All this petrologic features as well as features of dysaerobic biota suggest anoxic conditions occurred during the accumulation of the formation (Zhuravlev and Wood, 1996). There are debris flows in the Sinsk Formation in the AchchagyyTuoydakh section. The distinctive reefal facies of this age are not proved. In the Turukhansk-Irkutsk-Olekma Basin, the lowstand tract is represented by the lowermost dark mudstone of the Olekma Formation.

Highstand tract deposits are alike in all three basins. Their upper Botoman part are represented by the upper Olekma and Kutorgina formations and the lower Toyonian part consists of lower Chara, Barylay and Keteme formations (from West to East) (Varlamov and Sundukov, 1979). The Kutorgina Formation shows a shoaling trend from facies typical of the underlying Sinsk Formation in its base to small calcimicrobialarchaeocyathan reefs in its top, and the Olekma Formation changes upwards from dolomitic mostly mudstone to dolomitic gravelstone and sandstone (Varlamov, 1982). The upper set of formations indicate the progradation of lagoonal facies into the Anabar-Sinsk Basin and back-reef facies onto shelf, respectively. The back-reef Keteme Formation is composed mostly of Aulophycus facies characterised above (Astashkin, 1985).

\section{Sequence C2.1}

Middle Toyonian lowstand tract is indicated by a very distinct yellow cavernous (after anhydrite-gypsum dissolution) peritidal dolostone prograding far towards the East (middle Chara, Berdigestyakh and Titary formations) in the Anabar-Sinsk Basin. In the distal part of the Yudoma-Olenek Basin, this interval is characterised by condensed deposits of the Kuonamka Formation with hiatal surfaces (Bakhturov et al., 1988). Soluble potash salts were accumulated in the innermost Turukhansk-Irkutsk-Olekma Basin (Chechel' et al., 1981) indicating that this basin subjected to nearly complete desiccation (James and Kendall, 1992). The transgressive tract began from the spreading of reefal facies (upper Toyonian-lower Amgan Khomustakh, Amga and Elanskoe formations) westwards and culminated in the accumulation of widespread black shales in the Yudoma-Olenek Basin and the Kychik Formation chert and bituminous limestone in the AnabarSinsk Basin during the late Amgan time (Sukhov and Pereladov, 1979; Evtushenko, 1982). The lower Mayan highstand tract characterised by formation of subaerial plain in the Turukhansk-Irkutsk-Olekma Basin (Budnikov et al., 1995), formation of the "filling complex" (e.g., argillaceous mudstones of the Ust' Botoma and Chaya formations) in the Yudoma-Olenek Basin (Sukhov and Pereladov, 1979), and replacing of calcimicrobial (Gordonophyton) microframestones (Dereskir Formation) by mostly thrombolites (Tangha Formation) in the Anabar-Sinsk Basin.

\section{CONCLUSIONS}

1. Four sequences are recognised in the Lower and Middle Cambrian stage stratotype area of the Siberian Platform, in ascending order, lower Tommotian-lower Atdabanian sequence C1.1, lower Atdabanian-lower Botoman sequence C 1.2 , lower Botoman-middle Toyonian sequence $\mathrm{C} 1.3$ and middle Toyonian-lower Mayan sequence C2.1.

2. The stage boundaries do not coincide with sequence boundaries. The base of sequence C1.1 is within the Nochoroicyathus sunnaginicus Zone of the Tommotian Stage. The C1.1/C1.2 sequence boundary is within the Retecoscinus zegebarti Zone of the Atdabanian Stage, the $\mathrm{C} 1.2 / \mathrm{C} 1.3$ sequence boundary is within the Bergeroniellus micmacciformis-Erbiella Zone of the Botoman Stage, and the $\mathrm{C} 1.3 / \mathrm{C} 2.1$ sequence boundary is within the Lermontovia grandis Zone of the Toyonian Stage. The maximum flooding surface of the sequence C1.3, however, coincides with the base of the Bergeroniellus gurarii Zone (early middle Botoman Stage).

3. Remarkably, that $\mathrm{C} 1.1 / \mathrm{C} 1.2$ sequence boundary distinguished on the southern Siberian Platform is biostratigraphically correlated with $\mathrm{C} 1.1 / \mathrm{C} 1.2$ sequence boundary recognised in Eastern Officer and Arrowie basins of South Australia and sequence C2/C3 sequence boundary revealing in the Amadeus Basin of central Australia (Gravestock and Hibburt ,1991; Lindsay et al., 
1993; Zhuravlev and Gravestock, 1994). Also, the Siberian sequence C1.3/C2.1 boundary can be correlated with the Australian sequence $\mathrm{C} 1.3 / \mathrm{C} 2.1$ boundary. Thus, both these intervals may express global sea level changes. In the secon case, this is the Toyonian or Hawke Bay regression.

4. In general, the Siberian Platform was a large epeiric platform during the Cambrian. The facies profile indicates that during the accumulation of the sequences $\mathrm{C} 1.1$ and $\mathrm{C} 1.2$, the eastern (in modern coordinates) slope of the Siberian Platform developed as a distally steepened ramp in terms of Read (1981). The ramp turned into a rimmed carbonate shelf with accretionary margins at the beginning of the sequence $\mathrm{C} 1.3$ and shortly afterwards, during the transgressive tract deposition, it represented a drowned platform. Although the drowning was incipient and the platform became submerged to depths within the euphotic zone because abundant fleshy algae and cyanobacteria preserved in rocks representing the time of maximum flooding (Zelenov, 1955; Zhuravlev and Wood, 1996). The first two stages of the platform evolution were recognised by Astashkin et al. (1984) as "biohermal massif" and "mature reef" stages, respectively. During the rest of the accumulation of sequence C1.3 and following sequence C2.1, the drowned platform turned back into a rimmed shelf and, finally, at the end of the sequence C2.1, when filling complex accumulated, into a homoclinal ramp.

5. The transgressive tract facies contain the most cosmopolitan fauna, which are eodiscids (e.g., Calodiscus, Lenadiscus) in the sequence C1.3 and agnostids in the sequence C2.1 (Triplagnostus gibbus and Tomagnostus fissus-Paradoxides sacheri zones of the Amgan Stage). These levels possess the highest global correlative potential.

\section{ACKNOWLEDGEMENTS}

This study was supported by the Palaeontological Institute of the Russian Academy of Sciences (field seasons 1978, 1981, 1984, 1986-1987, 1989), Siberian ScientificResearch Institute of Geology, Geophysics and Mineral Resources (field season 1979) and in part by the Russian Foundation for Basic Research, project no. 96-05-64224. This paper is benefited from samples and thin sections and useful discussion provided by Vladimir Astashkin, Yuriy Shabanov, Sergey Sukhov (SNIIGGiMS, Novosibirsk) and Alexei Rozanov (PIN RAN, Moscow). Irina Maidanskaya is deeply thanked for the preparation of figures.

\section{REFERENCES}

Arkhangel'skaya, N. A., Grigor'ev, V. N. i Zelenov, K. K. 1960. Fatsii nizhnekembrijskikh otlozhenij yuzhnoj i zapadnoj okrain Sibirskoj platformy. [Lower Cambrian Sediment Facies of the Southern and Western Margins of the Siberian Platform.] Trudy Geologicheskogo Instituta, Akademija nauk SSSR, 33, 1-190. [In Russian.]
Astashkin, V. A. 1985. Problematichnye organizmyporodoobrazovateli $\mathrm{v}$ nizhnekembrijskikh otlozhenijakh Sibirskoj platformy. [Problematic rock-forming organisms in the Lower Cambrian deposits of the Siberian Platform.] Trudy Instituta geologii i geofiziki, Sibirskoe otdelenie, Akademija nauk SSSR, 632, 144149. [In Russian.]

Astashkin, V. A., Varlamov, A. I., Gubina, N. K., Ekhanin, A. E., Pereladov, V. S., Romenko, V. I., Sukhov, S. S., Umperovich, N. V., Fedorov, A. B., Fedyanin, A. P., Shishkin, B. B. i Khobnya, E. I. 1984. Geologija $i$ perspektivy neftegazonosnosti rifovykh sistem kembrija Sibirskoj platformy. [Geology and Prospects of Oil-GasBearing of the Cambrian Reef Systems of the Siberian Platform.] Nedra, Moskva. 181 pp. [In Russian.]

Astashkin, V. A., Pegel', T. V., Repina, L. N., Rozanov, A. Yu., Shabanov, Yu. Ya., Zhuravlev, A. Yu., Sukhov, S. S. and Sundukov, V. M. 1991. The Cambrian System on the Siberian Platform. International Union of Geological Sciences Publication, 27, 1-133.

Astashkin, V. A., Simon, T. S. and Voronova, L. G. 1993. The Cambrian of the south-western Siberian Platform. Cambridge Arctic Shelf Programme Report, 564, 1-63.

Bakhturov, S. F., Evtushenko, V. M. i Pereladov, V. S. 1988. Kuonamskaja bituminoznaja karbonatnoslantsevaja formatsija. [Kuonamka Bituminous Carbonate-Shale Formation.] Trudy Instituta geologii $i$ geofiziki, Sibirskoe otdelenie, Akademija nauk SSSR, 671, 1-160. [In Russian.]

Bobrov, A. K., Kolosov, P. N. i Val'kov, A. K. 1968. Sopostavlenie otlozhenij nizhnego kembrija vostochnoj i zapadnoj fatsial'nykh oblastej severnogo sklona Aldanskogo shchita. [Comparison of the Lower Cambrian sediments of the eastern and western facies regions on the northern slope of the Aldan Shield.] In: Tektonika, stratigrafija i litologija osadochnykh formatsij Jakutii. Doklady na XVII nauchnoj sessii YaF SO AN SSSR, Jakutsk [Tectonics, Stratigraphy and Lithology of Sedimentary Formations of Yakutia. Reports on the XVII Scientific Session of the Yakutian Department, Siberian Branch, USSR Academy of Sciences, Yakutsk] (Ed. K. B. Mokshantsev), 103-114. [In Russian.]

Brasier, M. D., Rozanov, A. Yu., Zhuravlev, A. Yu., Corfield, R. M. and Derry, L. A. 1994. A carbon isotope reference scale for the Lower Cambrian succession in Siberia: report of IGCP 303. Geological Magazine, 131, 767-783.

Brasier, M. D., Shields, G., Kuleshov, V. N. and Zhegallo, E. A. 1996. Integrated chemo- and biostratigraphic calibration of early animal evolution: Neoproterozoicearly Cambrian of southwestern Mongolia. Geological Magazine, 133, 445-485.

Budnikov, I. V., Sukhov, S. S., Devyatov, V. P., Lopushinskaya, T. V., Shishkin, B. B., Yadrenkina, A. G. and Kazakov, A. M. 1995. Stratigraphy and lithology of sedimentary cover from the western Yakutia. In: Sixth International Kimberlite Conference, Kimberlites of Yakutia, Field Guide Book. United Institute of Geology, Geophysics and Mineralogy, Novosibirsk, 27-34. 
Chechel', E. I., Mashovich, Ya. G., Gilev, Yu. G. i Chauzova, G. I. 1981. Nepskij kalienosnyj basseyn vostochnoj Sibiri i uslovija ego formirovanija. [The Nepa potassium-bearing basin of eastern Siberia and conditions of its formation.] In: Osnovnye problemy solenakoplenija. [Principle Problems of the Salt Accumulation.] (Eds. A. L. Yanshin and M. L. Zharkov). Nauka, Novosibirsk, 113-122. [In Russian.]

Debrenne, F. and Zhuravlev, A. Yu. 1996. Archaeocyatha, Palaeoecology: a Cambrian sessile fauna. In: Autoecology of selected fossil organisms: Achievements and problems. (Ed. A. Cherchi). Bollettino della Società Paleontologica Italiana, Special Volume, 3, Mucchi Editore, Modena, 77-85.

Evtushenko, V. M. 1982. Geologo-litologicheskij ocherk domanikitov kembrija Sibiri. [Geological-lithological essay on Cambrian domanikits of Siberia.] In: Domanikity Sibiri i ikh rol'v neftegazonostnosti. [Domanikits of Siberia and Their Role in the Oil-Gas Capacity.] (Ed. F. G. Gurari). Siberian ScientificResearch Institute of Geology, Geophysics and Mineral Resources, Novosibirsk, 100-107. [In Russian.]

Fedorov, A. B. 1982. Biostratigrafija i fatsii drevnejshego gorizonta nizhnego kembrija srednego techenija r. Aldana. [Biostratigraphy and facies of the Lower Cambrian oldest horizon in the Aldan River middle courses.] In: Stratigrafija i fatsii osadochnykh bassejnov Sibiri. [Stratigraphy and Facies of Sedimentary Basins of Siberia.] (Ed. V. A. Astashkin). Sibirskij NauchnoIssledovatel'skij Institut Geologii, Geofiziki i Mineral'nykh Resursov [Siberian Scientific-Research Institute of Geology, Geophysics and Mineral Resources], Novosibirsk, 18-25. [In Russian.]

Fedorov, A. B., Ermak, V. V. i Esakova, N. V. 1992. Nizhnjaja granitsa kembrija $\mathrm{v}$ opornykh razrezakh po $\mathrm{r}$. Aldan. [Cambrian lower boundary in reference sections in the Aldan River.] In: Kembrij Sibiri. [Cambrian of Siberia.] (Eds. A. Yu. Rozanov and L. N. Repina). Nauka, Novosibirsk, 11-20. [In Russian.]

Gravestock, D. I. and Hibburt, J. E. 1991. Sequence stratigraphy of the Eastern Officer and Arrowie basins: a framework for Cambrian oil search. The APEA Journal, 1991, 177-190.

Gurari, F. G. 1945. K stratigrafii kembrija yugo-vostoka Sibirskoj platformy. [On the Cambrian stratigraphy of the South-East of the Siberian Platform.] Izvestija Akademii nauk SSSR, Serija geologicheskaja, 1945 (4), 38-62. [In Russian.]

Ivanovskaya, T. A. 1980. Perekhodnye sloi kembrija i dokembrija v razreze Ulakhan-Sulugur (srednee techenie r. Aldan). [Cambrian and Precambrian transitional strata in Ulakhan-Sulugur section (middle courses of the Aldan River).] Izvestija Akademii nauk SSSR, Serija geologicheskaja, 1980 (1), 30-39. [In Russian.]

Ivanovskaya, T. A. i Tsipursky, S. I. 1982. Osobennosti glaukonita iz nizhnekembrijskikh otlozhenij razreza Ulakhan-Sulugur (srednee techenie r. Aldan). [Features of glauconite from the Lower Cambrian deposits of Ulakhan-Sulugur section (middle courses of the Aldan River).] Litologija i poleznye iskopaemye, 1982 (4), 79-
86. [In Russian.]

James, N. P. and Kendall, A. C. 1992. Introduction to carbonate and evaporite facies models. In: Facies Models: Response to Sea Level Changes. (Eds. R. G. Walker and N. P. James). Geological Association of Canada, Department of Earth Sciences, Memorial University of Newfoundland, St. John's, 265-275.

Kaufman, A. J., Knoll, A. H., Semikhatov, M. A., Grotzinger, J. P., Jacobsen, S. B. and Adams, W. 1996. Integrated chronostratigraphy of Proterozoic-Cambrian boundary beds in the western Anabar region, northern Siberia. Geological Magazine, 133, 509-533.

Khomentovsky, V. V. i Gibsher, A. S. 1983. Korrelyatsija razrezov nizhnego kembrija srednego techenija r. Lena $v$ perekhodnoj fatsial'noj oblasti. [Correlation of the Lower Cambrian sections of the transitional facies region in the Lena River middle courses.] In: Pozdnij dokembrij i rannij paleozoj Sibiri. Vendskie otlozhenija (Late Precambrian and Early Palaeozoic of Siberia. Vendian Strata). (Ed. V. V. Khomentovsky). Institut Geologii i Geofiziki, Sibirskoe Otdelenie, Akademija nauk SSSR [Institute of Geology and Geophysics, Siberian Branch, USSR Academy of Sciences], Novosibirsk, 3-15. [In Russian.]

Khomentovsky, V. V. and Karlova, G. A. 1993. Biostratigraphy of the Vendian-Cambrian beds and the lower Cambrian boundary in Siberia. Geological Magazine, 130, 29-45.

Khomentovsky, V. V. i Repina, L. N. 1965. Nizhnij kembrij stratotipicheskogo razreza Sibiri. [Lower Cambrian in the Stratotype Section of Siberia.] Nauka, Moskva. 200 pp. [In Russian.]

Khomentovsky, V. V., Val'kov, A. K. i Karlova, G. A. 1990. Novye dannye po biostratigrafii perekhodnykh vend-kembrijskikh sloev $\mathrm{v}$ bassejne srednego techenija $\mathrm{r}$. Aldan. [New data on the biostratigraphy of transitional Vendian-Cambrian strata in the Aldan River middle courses basin.] In: Pozdnij dokembrij i rannij paleozoj Sibiri. Voprosy regional'noj stratigrafii. [Late Precambrian and Early Palaeozoic of Siberia. Problems in Regional Stratigraphy.] (Eds. V. V. Khomentovsky and A. S. Gibsher). Institute of Geology and Geophysics, Siberian Branch, USSR Academy of Sciences, Novosibirsk, 3-57. [In Russian.]

Kirschvink, J. L., Magaritz, M., Ripperdan, R. L., Zhuravlev, A. Yu. and Rozanov, A. Yu. 1991. The Precambrian/Cambrian boundary: Magnetostratigraphy and carbon isotopes resolve correlation problems between Siberia, Morocco, and South China. GSA Today, 1, 69-71, 87, 91.

Knoll, A. H., Grotzinger, J. P., Kaufman, A. J. and Kolosov, P. 1995. Integrated approaches to terminal Proterozoic stratigraphy: an example from the Olenek Uplift, northeastern Siberia. Precambrian Research, 73, 251270.

Knoll, A. H., Kaufman, A. J., Semikhatov, M. A. and Grotzinger, J. P. 1995. Sizing up the sub-Tommotian unconformity in Siberia. Geology, 23, 1139-1143.

Kruse, P. D., Zhuravlev, A. Yu. and James, N. P. 1995. Primordial metazoan-calcimicrobial reefs: Tommotian 
(Early Cambrian) of the Siberian Platform. Palaios, 10, 291-321.

Lindsay, J. F., Kennard, J. M. and Southgate, P. N. 1993. Application of sequence stratigraphy in an intracratonic setting, Amadeus Basin, central Australia. Special Publications of International Association on Sedimentology, 18, 605-631.

Magaritz, M., Holser, W. T. and Kirschvink, J. L. 1986. Carbon-isotope events across the Precambrian-Cambrian boundary on the Siberian Platform. Nature, 320, 258259.

Mel'nikov, N. V., Astashkin, V. A., Kilina, L. I. i Shishkin, B. B. 1989. Paleogeografija Sibirskoj platformy v rannem kembrii. [Palaeogeography of the Siberian Platform in the Early Cambrian.] In: Paleogeografija fanerozoja Sibiri. [Phanerozoic Palaeogeography of Siberia.] (Ed. R. G. Matukhin). Sibirskij NauchnoIssledovatel'skij Institut Geologii, Geofiziki i Mineral'nykh Resursov [Siberian Scientific-Research Institute of Geology, Geophysics and Mineral Resources], Novosibirsk, 10-17. [In Russian.]

Morrow, D. W. 1978. Dolomitization of Lower Paleozoic burrow-fillings. Journal of Sedimentary Petrology, 48, 295-306.

Nazarov, M. A., Barsukova, L. D., Kolesov, G. M. and Alekseev, A. S. 1983. Iridium subabundance in the Precambrian-Cambrian boundary deposits and sedimentary rocks of the Russian Platform. 14th Lunar and Planetary Science Conference, Abstracts, 2, 546547.

Pel'man, Yu. L., Ermak, V. V., Fedorov, A. B., Luchinina, V. A., Zhuravleva, I. T., Repina, L. N., Bondarev, V. I. i Borodaevskaya, Z. V. 1990. Novye dannye po stratigrafii i paleontologii verkhnego dokembrija i nizhnego kembrija r. Dzhandy (pravyj pritok r. Aldan). [New data on the stratigraphy and palaeontology of the Upper Precambrian and Lower Cambrian of the Dzhanda River (Aldan River right tributary).] Trudy Instituta geologii $i$ geofiziki, Sibirskoe otdelenie, Akademija nauk SSSR, 765, 3-32. [In Russian.]

Pisarchik, Ya. K., Minaeva, M. A. i Rusetskaya, G. A. 1975. Paleogeografija Sibirskoj platformy $v$ kembrii (Cambrian Palaeogeography of the Siberian Platform). Nedra, Leningrad. 195 pp. [In Russian.]

Pratt, B. R., James, N. P. and Cowan, C. A. 1992. Peritidal carbonates. In: Facies Models: Response to Sea Level Changes. (Eds. R. G. Walker and N. P. James). Geological Association of Canada, Department of Earth Sciences, Memorial University of Newfoundland, St. John's, 303-322.

Read, J. F. 1981. Carbonate platforms of passive (extensional) continental margins: types, characteristics and evolution. Tectonophysics, 81, 195-212.

Riding, R. and Zhuravlev, A. Yu. 1995. Structure and diversity of oldest sponge-microbe reefs: Lower Cambrian, Aldan River, Siberia. Geology, 23, 649-652.

Rozanov, A. Yu. i Sokolov, B. S. (Eds.) 1984. Jarusnoe raschlenenie nizhnego kembrija. Stratigrafija. [Lower Cambrian Stage Subdivision. Stratigraphy.] Nauka, Moskva. 184 pp. [In Russian.]
Rozanov, A. Yu. i Zavarzin, G. A. 1997. Bakterial'naya paleontologija. [Bacterial palaeontology.] Vestnik Rossiyskoj Akademii nauk, 67, 241-245. [In Russian.]

Rozanov, A. Yu., Missarzhevsky, V. V., Volkova, N. A., Voronova, L. G., Krylov, I. N., Keller, B. M., Korolyuk, I. K., Lendzion, K., Mihniak, R., Pykhova, N. G. i Sidorov, A. D. 1969. Tommotskij jaarus i problema nizhnej granitsy kembrija. [Tommotian Stage and the Cambrian Lower Boundary Problem.] Trudy Geologicheskogo Instituta, Akademija Nauk SSSR, 206, 1-380. [In Russian.]

Rozanov, A. Yu., Semikhatov, M. A., Sokolov, B. S., Fedonkin, M. A. i Khomentovsky, V. V. 1997. Reshenie o vybore stratotipa granitsy dokembrija i kembrija: proryv $\mathrm{v}$ probleme ili oshibka? [Decision on the choose of the Precambrian and Cambrian boundary: The breach in the problem or a mistake?] Stratigrafija. Geologicheskaja korrelyatsija, 5, 21-31. [In Russian.]

Savitsky, V. E., Evtushenko, V. M., Egorova, L. I., Kontorovich, A. E. i Shabanov, Yu. Ya. 1972. Kembrij Sibirskoj platformy. [Cambrian of the Siberian Platform.] Trudy Sibirskogo nauchno-issledovatel'skogo instituta geologii, geofiziki i mineral'nogo syr'ja, 130, 1200. [In Russian.]

Savitsky, V. E., Astashkin, V. A., Egorova, L. I. i Shabanov, Yu. Ya. 1980. Stratigrafija i uslovija obrazovanija kembrijskikh otlozhenij Sibirskoj platformy (kontroliruyushchaya rol' rifovykh sistem $\mathrm{v}$ raspredelenii fatsij. Trudnosti v korrelyatsii). [Stratigraphy and conditions of the formation of Cambrian deposits of the Siberian Platform (control role of reef systems on the facies distribution. Difficulties in the correlation).] In: International Geological Congress, XXVI Session, Reports of Soviet Geologists, Paleontology, Stratigraphy. (Ed. B. S. Sokolov). Nauka, Moskva, 160-166. [In Russian with English abstract.]

Shabanov, Yu. Ya., Astashkin, V. A., Pegel', T. V., Egorova, L. I., Zhuravleva, I. T., Pel'man, Yu. L., Sundukov, V. M., Stepanova, M. V., Sukhov, S. S., Fedorov, A. B., Shishkin, B. B., Vaganova, N. V., Ermak, V. I., Ryabukha, K. V., Yadrenkina, A. G., Abaimova, G. P., Lopushinskaya, T. V., Sychev, O. V. i Moskalenko, T. A. 1987. Nizhnij paleozoj yugozapadnogo sklona Anabarskoj anteklizy (po materialam burenija). [Lower Palaeozoic of the Anabar Anteclise South-Western Slope (According to Borehole Data).] Nauka, Novosibirsk. 208 pp. [In Russian.]

Spizharski, T. N., Ergaliev, G. Kh., Rozanov, A. Yu. i Chernysheva, N. Ye. 1983. Yarusnaja shkala kembriyskoj sistemy. [The stage scale of the Cambrian System]. Postanovlenija Mezhvedomstvennogo stratigraficheskogo komiteta i ego postojannykh kommissij, 21, 22-31. [In Russian.]

Spizharski, T. N., Zhuravleva, I. T., Repina, L. N., Rozanov, A. Yu., Tchernysheva, N. Ye. and Ergaliev, G. H. [sic] 1986. The stage scale of the Cambrian System. Geological Magazine, 123, 387-392.

Sukhov, S. S. i Pereladov, V. S. 1979. Depressionnyj kompleks nizhnego i srednego kembrija vostoka Sibirskoj platformy. [Depression complex of the Lower 
and Middle Cambrian in the East of the Siberian Platform.] In: Geologija rifovykh sistem kembrija Zapadnoj Jakutii. [Geology of Reef Systems in the Cambrian of Western Yakutia.] (Ed. V. E. Savitsky). Trudy Sibirskogo nauchno-issledovatel'skogo instituta geologii, geofiziki i mineral'nogo syr'ja, 270, 50-60. [In Russian.]

Val'kov, A. K., Meshkova, N. P., Missarzhevsky, V. V. i Sysoev, V. A. 1983. Tip Khiolitozoa (Phylum Hyolithozoa). Trudy Instituta geologii i geofiziki, Sibirskoe otdelenie, Akademija nauk SSSR, 558, 55-96. [In Russian.]

Varlamov, A. I. 1982. Uslovija formirovanija olekminskoj i barylayskoj svit nizhnego kembrija i ikh stratigraficheskie sootnoshenija na severnom sklone Aldanskoj anteklizy. [Accumulation conditions of the Lower Cambrian Olekma and Barylay formations and their stratigraphic relationships on the northern slope of the Aldan Anteclise.] In: Stratigrafija $i$ fatsii osadochnykh bassejnov Sibiri. [Stratigraphy and Facies of Sedimentary Basins of Siberia.] (Ed. V. A. Astashkin). Sibirskij Nauchno-Issledovatel'skij Institut Geologii, Geofiziki i Mineral'nykh Resursov [Siberian ScientificResearch Institute of Geology, Geophysics and Mineral Resources], Novosibirsk, 56-73. [In Russian.]

Varlamov, A. I. i Sundukov, V. M. 1979. Otlozhenija zarifovoj otmeli kembrijskikh rifovykh sistem Zapadnoj Jakutii. [Back-reef shoal deposits of the Cambrian reef systems of Western Yakutia.] In: Geologija rifovykh sistem kembrija Zapadnoj Jakutii. [Geology of Reef Systems in the Cambrian of Western Yakutia.] (Ed. V. E. Savitsky). Trudy Sibirskogo nauchno-issledovatel'skogo instituta geologii, geofiziki i mineral'nogo syr'ja, 270, 31-49. [In Russian.]

Zelenov, K. K. 1955. O nizhnekembrijskikh morskikh bituminoznykh porodakh severnogo sklona Aldanskogo massiva. [On the Lower Cambrian marine bituminous rocks of the northern slope of the Aldan Massif.] Trudy Instituta geologicheskikh nauk, Akademija nauk SSSR, 155, Geologicheskaya seriya, 66, 116-135. [In Russian.]

Zhuravlev, A. Yu. 1995. Preliminary suggestions on the global Early Cambrian zonation. In: Morocco '95. The Lower-Middle Cambrian standard of western Gondwana. Introduction, Field Guide, Abstracts, and Proceedings of the First Conference of the Lower Cambrian Stage Subdivision Working Group and I.G.C.P. Project 366 Ecological Aspects of the Cambrian Radiation. (Eds. G. Geyer and E. Landing). Beringeria, Special issue 2, 147 160.

Zhuravlev, A. Yu. 1996. Aulophycus, Ketemella, Multivasculatus i drugie "izvestkovye vodorosli" i "gubki"-moshchnye bioturbatory kembrijskikh morej. [Aulophycus, Ketemella, Multivasculatus and other "calcareous algae" and "sponges"-power bioturbators of Cambrian seas.] In: Vserossiyskij simpozium Zagadochnye organizmy v evolyutsii i filogenii, Tezisy dokladov [All-Russian Symposium Enigmatic Organisms in the Evolution and Phylogeny, Abstracts] (Eds. V. N. Shimansky, A. Yu. Zhuravlev and An. F. Veis), 31-32. [In Russian.]

Zhuravlev, A. Yu. and Gravestock, D. I. 1994. Archaeocyaths from Yorke Peninsula, south Australia and archaeocyathan Early Cambrian zonation. Alcheringa, 18, 1-54.

Zhuravlev, A. Yu. and Wood, R. A. 1996. Anoxia as the cause of the mid-Early Cambrian (Botomian) extinction event. Geology, 24, 311-314.

Zhuravleva, I. T. 1979. Sakhajskaya organogennaja polosa. [The Sakha organogenic belt.] Trudy Instituta geologii $i$ geofiziki, Sibirskoe otdelenie, Akademija nauk SSSR, 431, 128-154. [In Russian.] 